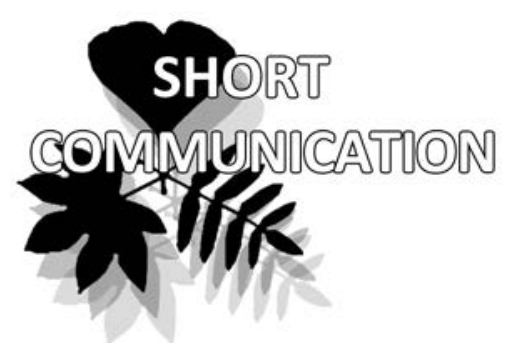

\title{
Megalospora porphyritis (Tuck.) R.C. Harris, a new record for Russia
}

Alexander K. Ezhkin ${ }^{1,2}$

e-mail: ezhkin@yandex.ru

${ }^{1}$ Botanical Garden-Institute FEB RAS, Vladivostok, Russia

${ }^{2}$ Institute of Marine Geology and Geophysics FEB RAS,

Yuzhno-Sakhalinsk, Russia

Manuscript received: $29 \cdot 09.2018$

Review completed: 15.10 .2018

Accepted for publication: 30.10 .2018

Published online: 31.10 .2018

\begin{abstract}
A B S T R A C T
A new finding of Megalospora porphyritis, previously known only from North America and Japan was registered on Sakhalin and Kuriles, Far East of Russia. The taxon is considered as a good example of an American/Asian disjunction most likely related to geological events in the Tertiary. Illustrations of lichen's morphological features and a map of finding points are provided.

K e y w o r d s : rare species, disjunction, relict, broad-leaved forest
\end{abstract}

\section{P E 3 Ю M E}

Ежкин А.К. Megalospora porphyritis (Tuck.) R.C. Harris, новый виА ААя России. Вил Megalospora porphyritis, известный с Северной Америки и Японии, был впервые обнаружен на Сахалине и Курильских островах на Аальнем Востоке России. Таксон может рассматриваться в качестве хорошего примера Американо-Азиатской Аизъюнкции, вероятно возникшей в результате геологических процессов в третичном периоде. В статье представмены фотографии мишайника, а также карта с точками нахожАения вида.

КАючевые слова: редкие виды, Аизъюнкция, реликт, широколиственный мес
The genus Megalospora (Meyen) consists of 50 mainly pantropical and tropical species (http://www.mycobank. org, accessed: 19 September 2018). Some species extends less far into temperate areas e.g. in North America, East Asia and Europe (Sipman 1983). Megalosporaceae (Vezda ex Hafellner \& Bellem.) species are generally found in humid forests locally known as "rainforest" and are common in suitable habitats. Many species with restricted distribution have become rare and might come in danger of extinction because of increasing forest harvesting (Sipman 1983). The Megalosporaceae have recently been confirmed to belong to Teloschistales D. Hawksw. \& O.E. Erikss. (Helms et al. 2003). The main character identifying Megalospora species is the heavily inspersed hymenium and often large apothecia with big transversely septate ascospores (Lücking 2007).

Megalosporaporphyritis has become the third species of the genus found in the Far East of Russia. M. tuberculosa (Fée) Sipman and Megalospora atrorubicans ssp. sendaiensis (Räsänen) Sipman were earlier registered in the Sakhalin Region (Insarov \& Pchelkin 1988, Konoreva et al. 2018). M. tuberculosa is quite common species on South Kuriles (Kunashir and Shikotan) and rare on Sakhalin. It occurs on bark of coniferous and deciduous trees and characterized by non-soredious thallus and big 8-10(12)-celled bacillar-pluriseptate spores. Megalospora atrorubicans ssp. sendaiensis is rarer in the region and found only on Kunashir Island mostly on bark of old coniferous trees. The species is widely distributed in Japan (Sipman 1983). It differs from other two species by bicellular spores and thallus chemistry (presence of usnic acid and lack of pannarin).
M. porphyritis was previously related to Tuberculosa complex and was included in that species in a wide sense (Sipman 1983). But Harris $(1984,1986)$ reported that the eastern North American temperate populations with pannarin, sorediate thallus (mostly sterile), pruinose apothecia, smaller and fewer-celled ascospores represent a separate taxon. Later the position was adopted by other authors (Lücking 2007). According to Sipman (1983) the North American population of $M$. porphyritis has definite similarities in morphological and chemical features with Japanese and Australian populations. But it is worth noting $M$. porphyritis is still not added as a separate taxon to Japanese and Australian lichen checklists at the moment. $M$. porphyritis is also close to another recently described sorediate species M. galapagoensis (Bungartz, Ziemmeck and Lücking) which is considered as a potentially endemic to the Galopogos Islands and differs from $M$. porphyritis by thallus chemistry (Lumbsch et al. 2011).

\section{MATERIAL AND METHODS}

All the material was examined using standard microscopic techniques with light microscopes MBS-10 and LOMO Mikmed 3. Identifications were done with the help of keys published by Lücking (2007). Natural compounds were characterized by high performance thin-layer chromatography (HPTLC) according to the methods standardized for lichen products (Arup et al. 1993). Spot tests were made with $10 \%$ of $\mathrm{KOH}(\mathrm{K}), \mathrm{Ca}(\mathrm{ClO})_{2}(\mathrm{C})$ and $\left[\mathrm{C}_{6} \mathrm{H}_{4}\left(\mathrm{NH}_{2}\right)_{2}\right]$ (P). Examined specimens are deposited in the Herbarium of 
Institute of Marine Geology and Geophysics (SAK). Dublets of the samples were stored in Herbarium of Botanical Garden-Institute FEB RAS (VBGI).

\section{RES U LTS}

Description: Thallus crustose, corticolous, $2-3 \mathrm{~cm}$ across, bluish grey, thick, smooth to uneven-rugulose. Soredia present, diffuse. Photobiont chlorococcoid. Apothecia are not numerous, scattered on the thallus, round, (0.5)1.8(2.5) mm diam., disc plane, slightly convex, epruinose, margin distinct, slightly prominent, $0.1 \mathrm{~mm}$ wide, grey-black to black. Excipulum brownish, K-; epihymenium olive brownish; hypothecium brown, 100-130 $\mu \mathrm{m}$ high; hymenium 150-200 $\mu \mathrm{m}$ high, colorless, densely inspersed with small oil droplets. Ascospores single, hyaline, muriform, 77-90 × 20-33 $\mu \mathrm{m}$ (Fig. 1). Secondary chemistry: pannarin and zeorin. Spot tests: Cortex $\mathrm{K}-, \mathrm{C}-, \mathrm{KC}-, \mathrm{P}+$ yellow; medulla $\mathrm{K}-, \mathrm{C}-, \mathrm{KC}-\mathrm{P}+$ yellow.

Specimens examined: the Russian Far East, Shikotan Island, Mt. Notoro, 4346'40.9296"N 146² $42^{\prime} 08.0495^{\prime \prime E}$, alt. 92 m, riparian broad-leaved forest with Acerpictum Thanb., on bark of Padus ssiorii (Fr. Schmidt) C.K. Schneid, 17 June 2017, leg. A.K. Ezhkin (SAK 1653, 1661). Sakhalin Island, Vavaiskoye lake surroundings, $46^{\circ} 36^{\prime} 35.9172 " \mathrm{~N}, 143^{\circ} 18^{\prime} 50.8968^{\prime \prime E}$, alt. 21 $\mathrm{m}$, coniferous forest, on bark of Picea jezoensis (Sieb. et Juss.) Carr., 1 August 2016, leg. A.K. Ezhkin (SAK 1662). Sakhalin

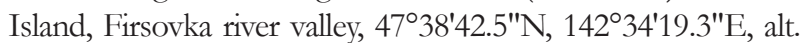
$18 \mathrm{~m}$, coniferous forest, on bark of Taxus cuspidata Siebold et Zucc. Ex Endl., 1 May 2017, leg. A.K. Ezhkin (SAK 1663).

\section{DISCUSSIO N}

A new finding of Megalospora porphyritis in the Russian Far East has become one more interesting species of the
Eastern Asiatic - Western North American group with a disjunctive range that it was recently added with some remarkable species of lichens from the genus Rinodina ((Ach.) Gray) (Sheard et al. 2017, Galanina et al. 2018) and the family Pannariaceae (Ezhkin \& Yørgensen 2018). In the Russian Far East $M$. porphyritis was occasionally found in coniferous and riparian broad-leaved forest areas in low and middle elevations not far from the coastline. North American population of $M$. porphyritis was found in very similar ecological conditions as Russian population - in moist coniferous and mixed hardwoods at different altitudes from 10 to 1500 $\mathrm{m}$ above sea level mostly near the coastline of the Atlantic Ocean (http://lichenportal.org) (Fig. 2A). Populations M. porphyritis of Sakhalin and Kuriles are relatively small and rare. The species was found only in three locations (Fig. 2B). The habitats of the lichen are limited by small forest areas with minimal human impact located on nature protected territories. Traces of old random wood harvesting with trees more than 120 years old were found on the studied territories so these forest areas could be considered as refugiums for the species. This suggests $M$. porphyritis to be a good example of Arcto-Tertiary relict lichen populations that were separated due to geological events in the past.

\section{ACKNOW LEDGEMENTS}

I am indebted to the following persons for assistance: Sergey Chesnokov for performing HPTLC, Lyudmila Konoreva and Felix Schumm for consulting the species. Special thanks to Scott LaGreca for providing the literature. The study was partly financially supported by the Russian Foundation for Basic Research (grants 18-04-00098).

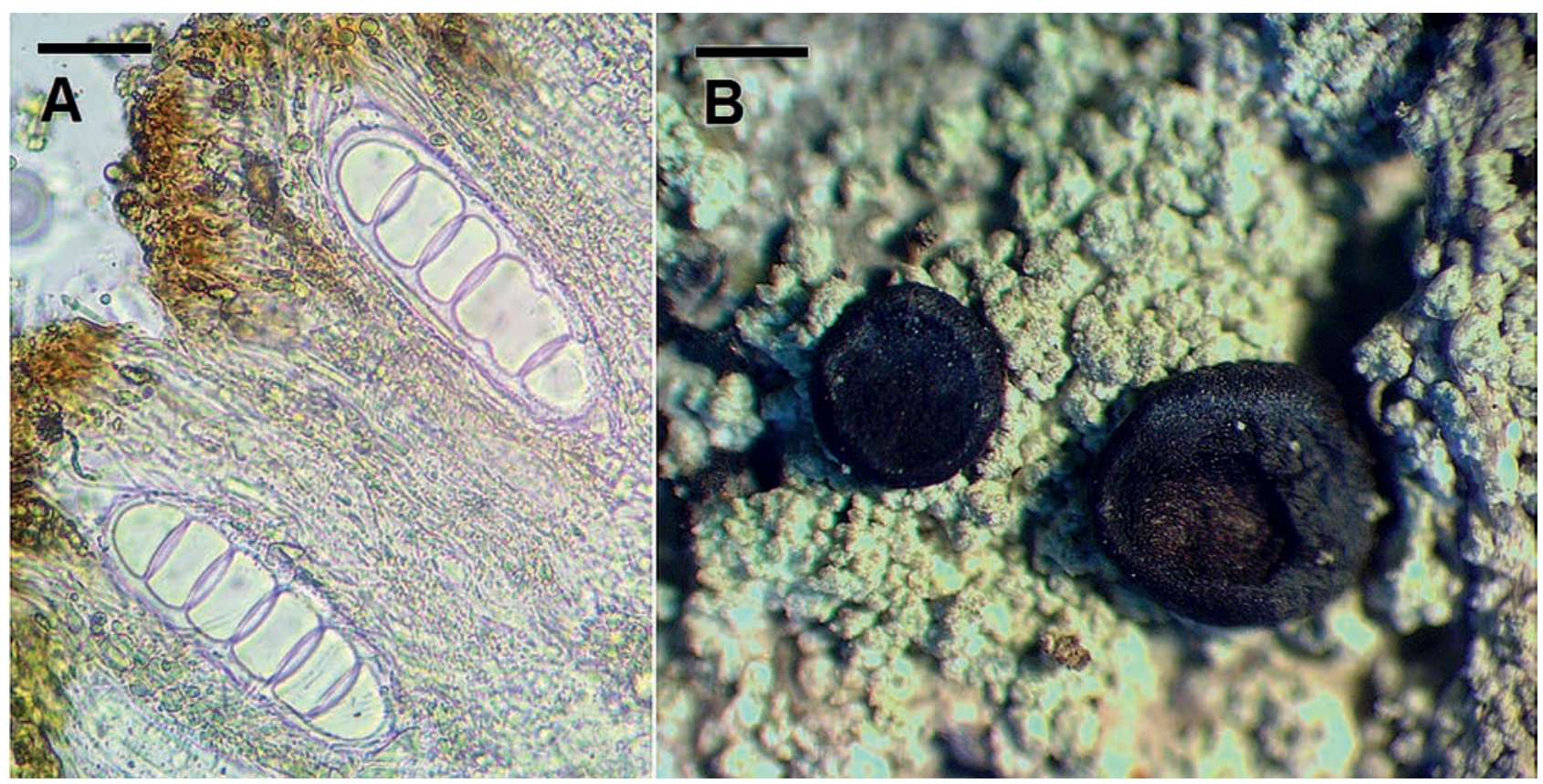

Figure 1 Megalospora porphyritis. A - apothecium in cross section with spores, B - thallus with apothecia. Scale bars: A = 50 $\mu \mathrm{m}, \mathrm{B}=1 \mathrm{~mm}$. 


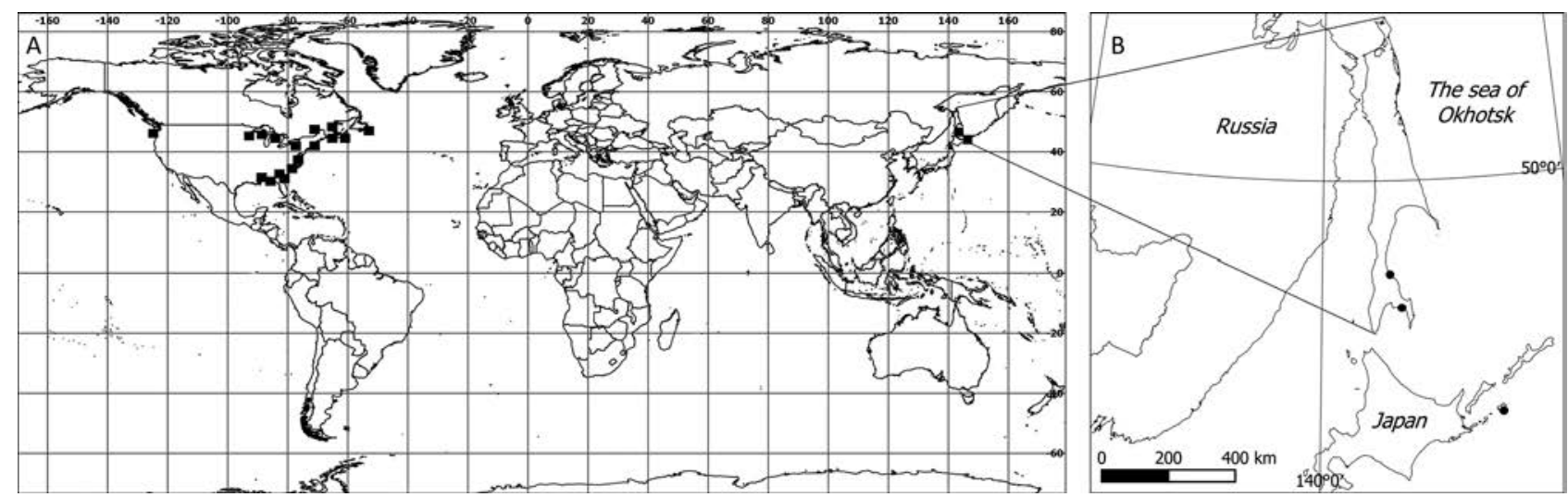

Figure 2 Distribution of Megalospora porphyritis in the World (http://lichenportal.org) (A) and the Sakhalin Region (B)

\section{LITERATURE CITED}

Arup, U., S. Ekman, L. Lindblom \& J. E. Mattsson 1993. High performance thin layer chromatography (HPTLC), an improved technique for screening lichen substances. Lichenologist 25:61-71.

Ezhkin, A.K. \& P.M. Jørgensen 2018. New records of Pannariaceae (lichenized Ascomycota) from Sakhalin and the Kuril Islands, Russian Far East. Evansia 35(2):43-52.

Galanina, I.A., A.K. Ezhkin \& L.S. Yakovchenko 2018. Rinodina megistospora (Physciaceae) in the Russian Far East. Novosti sistematiki niashikh rastenii 52(1):133-139.

Harris, R.C. 1984. Megalospora porphyritis in eastern North America. Evansia 1:24.

Harris, R.C. 1986. Megalospora porphyritis again: a reply to Sipman. Evansia 3:30.

Helms, G., T. Friedl \& G. Rambold 2003. Phylogenetic relationships of the Physciaceae inferred from rDNA sequence data and selected phenotypic characters. Mycologia 95:1078-1099.

Insarov, G.E. \& A.V. Pchelkin 1988. Quantitative charac teristics of the state of epiphytic lichen flora of Kurylskiy Reserve. The USSR State Committee for Hydrometeorology and Environmental Control, Moscow, 174 pp. (In Russian).
[Инсаров Г.Э., Пчелкин А.В. 1988. Количественные характеристики состояния эпифитной михенофморы Курильского заповедника. М.: Гос. комитет СССР по гиАрометеорологии АН СССР. 174 с.].

Konoreva, L.A., S.I. Tchabanenko, A.K. Ezhkin, F. Schumm \& S.V. Chesnokov 2018. New and noteworthy lichen and allied fungi records from Sakhalin Island, Far East of Russia. Herzogia 31(1):276-292.

Lücking, R. 2007. Megalospora imshangii sp. nov. and M. caraibica sp. nov. from Jamaica (Ascomycota: Teloschistales: Megalosporaceae) increase the number of American Megalospora species to ten. Fungal Diversity 27:103-110.

Lumbsch, H.T., T. Ahti, S. Altermann, G.A. De Paz, A. Aptroot, U. Arup, A.B. Pena, P.A. Bawingan, M.N. Benatti, L. Betancourt et al. 2011. One hundred new species of lichenized fungi: a signature of undiscovered global diversity. Phytotaxa 18:1-127.

Sheard, J.W., A.K. Ezhkin, I.A. Galanina, D. Himelbrant, E. Kuznetsova, A. Shimizu, I. Stepanchikova, T. Göran, T. Tønsberg, L.S. Yakovchenko \& T. Spribille 2017. The lichen genus Rinodina (Physciaceae, Caliciales) in northeastern Asia. Lichenologist 49(6):617-672.

Sipman, H.J.M. 1983. A monograph of the lichen family Megalosporaceae. Bibliotheca Lichenologica 18:1-241. 